\title{
Protection of women rights through legal reforms in Pakistan
}

\author{
Naveeda Noreen (Corresponding author) \\ Department of Political Science \\ The Islamia University of Bahawalpur, Pakistan \\ Prof. Dr. Razia Musarrat \\ Chairperson, Department of Political Science \\ The Islamia University of Bahawalpur \\ Bahawalpur, Pakistan
}

Accepted: December 27, 2013

doi:10.5296/ jpag.v3i4.5059 URL: http://dx.doi.org/10.5296/ jpag.v3i4.5059

\begin{abstract}
This paper presents the status of women rights in Pakistan and protection of these rights under the umbrella of legal reforms. After independence the women of Pakistan played an active role in nation building activities as well for their own social uplift. International organizations played special attention towards the issue of women empowerment During Ayub Era Muslim Family Law Ordinance 1961 was promulgated which is regarded as a first step forward for the protection of women rights. During Zia regime discriminatory laws were introduced which disturbed the equilibrium between male and female in the society. These laws put a negative impact on the status of women. Women organizations protested against Hudood Laws and demanded to repeal it. During the period of Musharraf new laws were introduced for the protection of women rights(women Protection Act 2006), it is regarded as golden era in context of legislation made for women empowerment .The process of legal reforms is in progression. The women are still subjugated to many criminal acts like harassment at work place ,attempted rape and acid throwing. There is a need of devising effective implementation mechanism in true letter and spirit for the safeguard of women rights.
\end{abstract}

Keywords: Empowerment, regime, harassment, discrimination, reforms 


\section{Introduction}

The process of women enlightenment and empowerment which was started during Musharraf regime remained in progress during the period. The struggle of women activists which started soon after the creation of Pakistan and got momentum after the promulgation of discriminatory laws of Zia period has seen the dawn of the progressive and enlightened Pakistan for women where the process of reconciliation has been started. Although the process of establishing a democratic and safe state for the women and the enforcement of human rights in its real sense still has a long way to go in Pakistan. Women's rights protection by legal reforms got a bloom in the year of 2006 by the enactment of Women Protection Law. Protection of Women Act was the result of the continuous demand from national and International women organizations and commissions.

Pakistan has made many international commitments for the protection of women and human rights. A series of these commitments are as follows which paved the way for protection of women rights and empowerment.

\section{Pakistan and the United Nations Commitments}

United Nations which came into being soon after World War II as a mediator of world peace, took the issue of women rights seriously. United Nations Charter specified equal rights for men and women in a way that no previous international legal document had (Thomsen, 2010, p.40). The movement for the protection of women rights was started in different countries at different times. The women suffrage movement was the first one which fought for legal protection. The women of the world over were concerned to get the right to vote. This was the agenda of United Nations to extend suffrage rights to all the women of member states but women could not get this right unless their own countries provide it a legal protection (Thomsen, 2010, p.41). Although the cultural barriers restrict women to use this right but protection of this right by law in a country is considered primary. Women started demanding civil rights after getting the suffrage right. They demanded civil rights in other areas of life like property rights, economic rights and social rights. Soon after its emergence Pakistan became the member of United Nations.

\section{United Nations Declaration of Human Rights 1948}

This declaration was the first example of women's new presence at the forefront of the international scene (Khan, 2009, p.27). The Universal Declaration of Human Rights (UNDHR) was the initial declaration which was signed by Pakistan. In this way all the United Nations declarations and resolutions of the United Nations Security Councils were applicable for Pakistan.

\section{United Nations Commission on the Status of Women (1946)}

In 1946, the United Nations Commission on the Status of Women was set up on account of the continuous disregard of the human rights of women in all over the world. This Commission was established to secure equal political, economic and educational rights and opportunities for women throughout the world (Patel, 2010, p.49).Pakistan has shown its 
commitments to International human rights treaties. United Nations always responded positively to all the women rights and demands. The UN Convention on the Political Rights of Women was adopted by the General Assembly in 1952, and The UN Convention on the Nationality of Married Women was adopted in 1957 followed by the convention on the consent to Marriage, Minimum Age for Marriage and Registration of Marriage adopted in 1962.The Forward Looking Strategies for the Advancement of Women in 1985. Pakistan also ratified the Convention on the Rights of the Child (CRC) in 1990 and in 1993.

\section{The Fourth World Conference on Women Beijing 1995}

Pakistan participated in 1995 in the fourth World Conference on women in Beijing as called Beijing platform for action. This Conference clearly stated that, it is an agenda for women's empowerment. Since 1995 there appeared a paradigm shift towards women and gender development issues (Mitra\&Bacchan, 2004, p.77).It became clear in this conference that now the focus would be on gender equality and human rights. It was recognized in this conference that violence against women is a serious obstacle in women development so it was adopted as one of the twelve critical concerns in the platform for Actions (Gooneskere, 2004, p.148). In this Conference Pakistan participated and after this with the consultation and involvement of the civil society developed a National Plan of Action. This Conference highlighted three main areas economic advancement, equal rights and violence against women .Pakistan also adopted this and as a key follow up as per para 297 of the platform for action formed National Plan of Action(NPA,MOWD,1998,p.1).

Pakistan also signed The Forward Looking Strategies for the Advancement of women (FLSAW) in Nairobi in 1985 The Programme of Action agreed at the International Conference on Population and Development (ICPD) in 1994 at Cairo, and World Summit on Social Development. The programme of Action agreed at the International Conference on Population (WSSD) in 1995 at Copenhagen and Pakistan acceded to the Convention on the Rights of the Child (NPA, MOWD, 1998, p.2).

All these treaties and conventions are to safeguard women's rights and to eradicate violence against them .The most important between them was the CEDAW. The basic aim of the commission was to secure equal political, educational and economic rights and opportunities for women throughout the world.

\section{Convention on The Elimination of All Forms of Discrimination Against Women (CEDAW) 1996}

Pakistan participated in the 'Beijing Declaration which was the agenda for the empowerment of women. Under this declaration it was recognized that women have unequal status in the society. It was committed in this declaration that it is the due right of women to ensure all the basic and fundamental rights to women and all the barriers which are creating hurdles in their way should be abolished. Beijing Conference was a catalyst for Pakistan accession to CEDAW. Pakistan signed CEDAW in 1995 and ratified it on March 11, 1996. Pakistan women activists were demanding to ratify the CEDAW since 1983(Hellum\&Aasen, 2013, p.436). 
CEDAW was adopted by United Nations General Assembly on $18^{\text {th }}$ December 1979 and was enforced as an international treaty on $3^{\text {rd }}$ September 1981 till 1989 almost hundred countries ratified it. It was the culmination of more than thirty years of work by the United Nations Commission on the Status of Women which was established in 1946 with the purpose to monitor the women situation and safeguard rights of women (Patel, 2010, p.50). This convention took an important place due to the considering of women who were half of the population of the world into the focus of human rights concerns. This convention established the equality of gender and advised countries to guarantee women rights equal to men. This convention from its preamble acknowledged that "extensive discrimination against women continues to exist" and emphasized that this discrimination totally violates the principles of equality of rights and respect for human dignity (CEDAW)

In article one the discrimination was defined as "any distinction, exclusion or restriction made on the basis of sex in the political, economic, social, civil and cultural or other fields". This convention required from all state parties to take all appropriate measures including legislation, to ensure the development and advancement of women for the purpose of guaranteeing them to exercise and enjoyment of human rights and fundamental freedom on the basis of equality with men. Under this convention the legal status of women received the greatest attention. In article $2(\mathrm{~F})$ it was affirmed that states should take all appropriate measures, including legislation to modify or abolish exiting laws, regulations, customs and practices which constitute discrimination against women CEDAW.

During the government of Benazir Bhutto and Nawaz Sharif despite an early ratification of the CEDAW little has been done to according to CEDAW. This was due to the political instability in Pakistan from 1988 to 1999. Pakistan did not submit even a single report to the CEDAW committee until 2004. In 2004 Pakistan submitted a report which was consisted of two hundred pages but after that one hundred pages report was submitted which was also shared with non- governmental organizations and civil society for inputs and comments. It was due to the better commitment under CEDAW that Pakistan in terms of legislation, Criminal Amendment Act 2004 was enacted (UNCEDAW, verdict, 2007). Pervaiz Musharraf was very much concerned towards the better and soft image of Pakistan of position in the world. He introduced laws and repealed the discriminatory laws towards women.

\section{The Grounds for Women Protection Act 2006}

In July 2005 the report prepared by the Ministry of women Development was submitted to the committee of CEDAW. The committee appreciated Pakistan for various legal reforms which were executed by the government of Pakistan as the adoption of National Plan of Action in 1998, National policy for advancement and empowerment of women in 2002. Legal Framework Order 2002 provided women's political participation and amendment in Pakistan Citizenship Act in 2002. Human Trafficking Ordinance 2002, Criminal Law Amendment Act in 2004 facilitated prosecution of honor killing and the Gender Reforms Actions Plan in 2005. The reorganization of ministry of women development and the creation of National Commission on the Status of Women in 2000 and financial structure as First Woman Bank(UNCEDAW,verdict,2007). Women activists and National and International 
organizations were protesting against the Hudood Ordinance 1979 by considering it discriminatory law towards women. The political governments after Zia regime came to power with the promise of repealing the Hudood Ordinance but did not bring any change in the prevailing laws due to the comprises made for the political stability. General Pervaiz Musharraf had started the process by the promulgation of Criminal Law Amendment Act 2004.

The changes in Hudood laws introduced by Zia were molded by the male chauvinists by their own likes and dislikes. Under this law instead giving punishments to rapists the law was used to punish the rape victims as alleging them for committing crime as adultery (DawnNews,4,2006). The reality was that the Hudood laws were defective and were adopted under a pedant military regime(DawnNews,6,2006) It was needed to be debated in the parliament and the discriminatory provisions should be repealed. On March 9, 2006 a seminar was organized by Aurat foundation Peshawar and urged the government to change the Hudood laws, declaring that these laws had been a cause of women's victimization from decades and declared the Hudood Ordinance a man made law but Zia regime called it an Islamic law(DawnNews, 9,2006).

Eighty percent women languishing in jails were victims of the Hudood laws and women in jails were also being victims to physical and sexual abuse. Thousands of women were in prison due to the Hudood Ordinance. According to Human Rights Commission report women of different ages were kept in jails with the charges of zina from 70 years women to 11 years girls.(HRC,2006,p.11-12). In each year 1500 cases were registered against women. 3,399 appeals in zina cases were presented before the Shariat court. Women activists condemned these situations by conducting different seminars and meetings and strongly demanded the repeal of discriminatory law, Hudood Ordinance (Jahangir\&JIllani, 1990, p.79).Parliamentarians Commission for Human Rights (PCHR) also firmly supported that Islam and constitution of Pakistan gave high status and position to women. (PCHR) submitted many bills dealing with the issues of women rights as amendments in the Hudood Ordinance, Honor killing, Bill on Domestic violence as well as amendments in the Qazf and offence of zina and the clauses of code of criminal procedure, Family Bill 2005, West Pakistan Family courts amendments Act 2004, Prohibition of marriage with Quran Act, 2005 and working women protection bill 2005 (DawnNews,10,2006). But the most controversial act to which women and civil society wanted urgent repeal was the zina Ordinance in which it was demanded same proves in the cases of zina and zina-bil-jabar. The evidence of four pious male was required, it was almost impossible for the rape victims to prove, or present four evidences before the court. In this way the victims of rape remained in the danger of being prosecuted under this law. Most of the criminal cases which were presented before the court under the Hudood Ordinance were related to zina ordinance(Otte,2010,p.418). The Hudood Ordinance had become the cause of injustices with women in the society. It was clear by the evidence that the most accused persons were acquitted by the appellate courts who were declared culpable by trial court (ShirkatGah, 2004, p.2). The Women rights activists and human rights organizations were constantly condemning these Hudood Ordinances as the severe violation of human rights. They declared it as so called Islamic legislation in which the 
interest of man was involved. They challenged this Ordinance as oppressive, discriminatory and un Islamic. They conducted researches and gathered data to prove that this law was totally discriminatory and in conflict with the principles of justice. They protested and engaged in lobbying to repeal the discriminatory law towards women. These women activists fought the war to repeal these laws for twenty seven years (NCOSW, 2006, p.2).

It may be said that this law was creating embarrassment for Pakistan as the signatory of CEDAW, which was demanding member states to bring their domestic laws in conformity with the International Law. Although the efforts were originated to review the Hudood Ordinances by the governments as in 1991 the report of the Inquiry Commission and in 2003 the National Commission on the Status of Women. Both these recommended to repeal these discriminatory laws, these reports declared the Hudood Ordinances as discriminatory and against the teachings of Islam(NCOSW,2006,p.3).

General Parvaiz Musharraf struggled to project a more liberal image of Pakistan at the global level but the Hudood Laws were reflecting a very passive and orthodox image of Pakistan because women as well as human activists at local and global level were constantly criticizing the Hudood Ordinance. The government appointed three commissions to examine the Hudood Ordinance. Two of them suggested to repeal them. They recommended that it is necessary to repeal the Hudood Laws and Pakistan Penal Code 1860's repealed provisions should be re-enacted. However inquiry report suggested that there is a need of serious debate if parliament wants to make further laws(Oette,2011,p.261).

The National Commission on the Status of Women(NCSW) formed a special committee consisted of eighteen members to review the Hudood Ordinance. This committee was consisted of the Supreme Court, High Court and Federal Shariat Court, lawyers, religious scholars and women rights activists. This committee recommended that these laws should be repealed because these were creating injustice in the society instead of justice (Oette,2011,p.261).

\section{Women Protection Act 2006}

In June 2006 the process to repeal the Hudood Ordinance was started. General Pervaiz Musharraf called upon religious scholars to give recommendations in order to repeal the Hudood Laws. The Council of Islamic Ideology recommended that the state should rewrite the Hudood Laws and these laws should be in consonance to the Quran and Sunnah as well as incorporate to the Pakistan's Penal and Criminal Procedure Codes.

It was finally decided that the laws concerning to zina should be reformed. The cabinet approved the draft amendments and a committee consisted of five ministers was set up to table the bill in the National Assembly. Although The Protection of Women Act 2006 was tabled by the Federal government in August. Jamat-e-Islami protested against the bill. They considered and declared it un-Islamic and the cause of vulgarity and westernization in the country. They claimed that this bill will not provide any protection to women rather will block the way of protection of women. However on $1^{\text {st }}$ December 2006 The bill was promulgated after receiving the assent of the President General Pervaiz 
Musharraf(DawnNews, $1^{\text {st }}$ jan,2007).In its preamble it was stated that "it is necessary to provide relief and protection to women against misuse and abuse of law and to prevent their exploitation"(Gazette of Pakistan, $2^{\text {nd }}$ Dec,2006).

The causes and reasons to repeal the laws is stated in the act that is to bring in particular the laws relating to zina and Qazf in conformity with the stated objectives of the constitution and the injunctions of Islam.

In Pakistan Penal Code (Act XLV of 1860) sections 365B, 367A, 371A, 371B were inserted which dealt with abducting, Kidnapping or inducing women to compel for marriage as well as abducting or Kidnapping for the unnatural lust, selling the persons for the purpose of prostitution or buying the persons for the purposes of prostitution, all shall be punished with death or rigorous imprisonment for a term which may extend to twenty five years and shall also be liable to fine (Gazette of Pakistan, $2^{\text {nd }}$ Dec,2006).

The new sections 375 and 376 under the heading of rape were inserted in which "A man who will commit rape against the will or consent or in a situation where a man got consent after indulging her in a fear of hurt or death or in the case of where man knows that he is not married to her and she agreed or showed her consent because she believes that the man is that whom she is or believes herself to be married or got a girl's consent who is under the age of sixteen years would be liable to be punished as death or imprisonment not less than twenty five years." In this way the punishments for rape had been repealed. In the case of gang rape each will face same punishments. In this way the victim of rape would be no more bound to produce four male pious eye witness Muslims to present evidence. The person who will complaint or come with the charge of rape will not face the charges of zina and the circumstantial evidences would be required to investigate the cases(Gazette of Pakistan, $2^{\text {nd }}$ Dec,2006).

The Protection of Women Act 2006 declared all the sexual acts of men against women under the age of sixteen and marital rape as an offense and these acts would be punishable under the insertion of new sections 493A, 496A, 496B and 496C. The man who cohabitates deceitfully inducing a belief of law- full marriage or take away women with criminal intent would face punishment of either description for a term which may extend to seven years and shall also be liable to fine. The protection of women act 2006 changed the reporting procedure of zina. It was required from the complainant of zina falling under Hadood to come in the Session Court with the four pious Muslim witness evidences. One who would not be able to bring proves would be punishable under the Qazf. The punishment of fornication "shall be imprisonment for a term which may extend to five years and shall also be liable to five" same punishments were for false accusation of fornication.

The Women Protection Act 2006 moved all the provisions of zina Ordinance back to the Pakistan Penal Code. However the Hadd punishment for zina was excluded from it. The zina-bil-jabr offence was also moved back to the Pakistan Penal Code (PPC) and the procedure for the prosecution of the Tazir offences of zina-bil-jabr and gang rape, are for all other Tazir offences under the Pakistan Penal Code is to be regulated by the code of criminal procedure 1898 (NCSOW,2006,AWPA,p.3). 
Under this law the Hadd punishment for rape were repealed. The police could not keep a woman in police station for more than twenty four hours. Police was forced to bring and present the women in front of the magistrate within the period of twenty four hours and to send the women in the judicial custody.

The definition of marriage which had become problematic was also changed under this law. Although this law was given the name of protection against women or Women Protection Act but it did not provide the umbrella of protection to women totally because the key demands which the women rights activists made in their campaign as the change of rape laws were not included in the new rape definition as well (Gazette of Pakistan,2011,p.266).

\section{Protection of Women Act 2006 And Its Impacts}

The women activists and committees established to ponder the Hudood Laws and to give recommendations, all recommended to repeal the Hudood Laws totally but this new law introduced amendments in only two of the ordinances and these were the changes in zina and Qazf ordinances.

The age of consent was not fully explained as was in the zina ordinance, where a person who got puberty is considered an adult. Many other flaws remained in the new law but it was a step towards the protection of women(NCSOW,2006,AWPA,p.4). It took twenty five years process to expose the discriminatory and injustice nature of the law. Although the human rights organizations and women activists were constantly demanding to repeal these law from the very early period after the enactment of discriminatory Hudood Laws but little efforts were put from the religious segments of the society. However Women Protection Act effectively guaranteed the rights to women.

The overall impact on women was positive. This can create hurdles towards the misuse of the zina ordinance. The law provided great relief to women and women got protection against the false charges of zina.

A radical change came after the promulgation of this act in the reduction of zina charges against women. It blocked the path of false FIRs in the cases of zina because after the enactment of new law it becomes difficult for the people to wrongly implicate the people on the charges of adultery or zina.

Before the introduction of this law the women were reluctant to register the cases of rape. The data also shows that cases of domestic violence, harassment at work place are not being reported by the women.

It is said that the new law has changed nothing because women living in the rural areas and feudal society can get least advantage because the bill is criticized badly from the Islamic fundamentalist parties. They believe that this new law will make Pakistan a free sex zone and will provide cover to prostitution. However women welcomed this law and declared it a step towards the protection of their rights. 


\section{Code of Criminal Procedure (Amendment) Ordinance, 2006}

On $7^{\text {th }}$ July 2006 an ordinance promulgated by Parvaiz Musharraf President of Pakistan by amending the 496 and 497 of Cr. P.C. The objective of this ordinance was to facilitate release of women detained on various charges including violation of Hudood Laws(Sehgal,2006,p116). This ordinance to grant bail to the persons who were in jails may be released on bails but the person would not be released who had the charges of terrorism and murder (Law\& Justice commission of Pakistan). Through this ordinance 848 women got released from the jails of the different provinces of the country.

The year 2007 was the last parliamentary year of the government. In this year seventeen private member bills were moved. The National Assembly during its tenure referred all the bills to with the directives to standing committee(Mirza,2011,p.1). The year 2007 saw the assassination of Benazir Bhutto a horrifying event for the whole country and especially for women. She was the symbol of courage and empowerment for Pakistan women. She was shot dead in a Suicide bomber attack in Rawalpindi soon after end of her address to an election campaign there. Due to this horrible incident the election was delayed and new Pakistan people's party government came to power after the elections held in 2008 (Year Book,MOWD,2008).

However National Assembly standing committee on women development held many meetings to address the women rights issues in the country. The one meeting held on $12^{\text {th }} \mathrm{July}$ 2007 on the policy of status of home based women working in the parliament house third, meeting on $30^{\text {th }}$ August was held to address the plans for women development and they proposed recommendations for the development of women(Year Book,MOWD, 2007).

In the year 2007 a Pakistani delegation officially submitted the $I^{\text {st }}$ Pakistan CEDAW report to the UNCEDAW committee in New York in which they told about the repeal of Hudood Laws (Hellum\&Ann,2013, p.436). In the year of 2008 the process of making new laws continued by the National Assembly, women activists and the Ministry of Women Development (MOWD). The process which was started by the previous National Assembly and had been tabled by Ms. Sherry Rehman and Ms. Mehnaz Rafi, both bills were clubbed together by the Ministry of Women Development.

Another bill was drafted by the Aurat foundation and they got help from the justice (Retd.) Nasira Javed Iqbal, another bill was drafted on domestic violence by UNIFEM and the next was the bill which was tabled by Ms. Yasmeen Rehman this was a private member bill. In 2008 the (UNIFEM) and Aurat foundation merged their bill and discussed with other stake holders. In the last, the draft bill was handed over to National Assembly and the standing committee under the chairperson of Bushra Gohar discussed and presented the final draft and on $4^{\text {th }}$ August 2009 and bill was passed by the National Assembly(Mirza,2011,p.1).

The process to propose this bill started in 2005, bill was passed by the National Assembly in 2009 , but was lapsed by the Senate. The three months limitation to approve the bill passed and no new development by the Senate came forward. The changes which came due to the eighteenth amendment in the constitution also brought changes in the legislative process. 
However in the year 2010 two laws were passed by the government (Mirza,2011,p.1).

\section{The Criminal Law Amendment Act, 2010}

This law was a milestone for the protection of women rights and protection of women in Pakistan. In our society most of the people think that the place of women is in the four walls of home and they need nothing to do outside. The women who want to take part in economic or other social activities, they have to face many hardships. This segment of the society think that if women came out they should harass and block their way to come out of their houses.

Sherry Rehman was the architect of this law. In this law sexual harassment was declared a crime which would be punishable by law. This law was not mentioned as a crime in the PPC of 1862(Shahidulah, 2012, p.496).

This law brought amendments in section 509 of the PPC which were relating to sexual harassment of women at work place. This was a marvelous piece of law which was only for protection of women rights. It was explained in this law that "whoever intending to insult the modesty of any woman, utters any word, makes any sound or gesture, or exhibits any object intending that such word or sound shall be heard, or that such gesture or object shall be seen, by such woman, or induces upon the privacy of such women." The person who conducts sexual advances or uses verbal or non verbal communication or physical conduct of a sexual nature and the act which put effect on the work and employment of a person would be called an offence and that offence should be punished with imprisonment which could be extended to three years or with the fine up to five hundred thousand rupees or with both(Gazette of Pakistan2010).

This bill relates to the right of the dignity of women. This bill was welcomed by the civil society and women activists. They consider this bill as a first bill in the country's history which provided protection against sexual harassment to women. Women have the right to feel secure in the public and private domain. So this proved as a first step towards the security of women. After the enactment of this act there is a dire need for women to have a safe workplace where they could work better and to the best of their abilities and could work properly for their wellbeing and for the betterment of their country. Alliance Against Sexual Harassment (AASHA) was also the part of drafting the bill. So this law defined sexual harassment as it is one of the common problems Pakistani women faced in daily routine. Under this act with the additional clause which refers to what constitutes harassment. The law had explained the places where these activities can happen at public transport, markets, parks and in the streets, in the private domains like work places, private gatherings or homes(Patel,2010, p.43).

However women activists are also demanding that this offence should be non-bailable. When this act came seveal women activists forged a definition of this term.

Hina Jilani a leading women activist defined the term as "any kind of verbal or physical intimidation of a woman or any act that inclines that her modesty is being undermined". It includes all kinds of harassment be it at workplace or in private sphere, for example stalking someone on the road, doing any action while the girl is passing by. Majority of the cases of 
harassment in our society happen in public transport(Jillani,1990,p.2).

.Harassment of women at work or public places is a very serious issue because if women will face hurdles at workplaces and public places they will hesitate to come out, in this way they would not be able to get their economic rights and will not feel secure. Pakistan's constitution does not make any discrimination between men and women. So the purpose of this law is to create a secure environment for working women.

The incident of 2006 when a member of Provincial Assembly in Sindh was suspended by the speaker of the Assembly because a woman member of the Provincial Assembly complained against him on harassing her by writing notes. In Pakistan the incidents of harassing the female worker have become a routine matter. The girl students are mostly harassed by male teachers, nurses are harassed by doctors and patients, workers in the organization harassed by their company workers or male bosses(Patel,2010,p.43).

In Pakistan the situation of women is aggravated due to the crime of harassing. At public places women faces rude comments. Under this law women would be able to act that they could complain against these offences.

In 2003 an alliance against sexual harassment at the work place which was a national alliance of six organizations was established. This alliance struggled hard to curb sexual harassment of women at workplace and drafted the law against this crime.

\section{Protection Against Harassment Of Women At The Workplace Act 2010}

On January 21, Senate passed bill Protection against Harassment of women. The objective behind this law was to make a code of conduct and this code of conduct would be an anti sexual harassment policy which would be the part of every registered organization. In this law the definition of sexual harassment and other concerning terms were explained comprehensively. It is stated in this law that every organization will have to form a committee which would be comprised of three members and at least one member among the three should be a woman. This committee will gather complaints of sexual harassment. Sexual harassment is defined in the Act 2010 as "Any unwelcome sexual advance, request for sexual favors or other verbal or written communication or physical conduct of sexual nature or sexually demeaning attitudes, causing interference with work performance or creating an intimidating, hostile or offensive work environment or the attempt to punish the complainant for refusal to comply to such a request or is made a condition for employment"( Raja,2010,p.41).

This law made it essential for every organization to have a code of conduct and a standing committee to deal the issues. Anybody who is the perpetrator of sexual harassment and committee found it not easy to hold accountable then this case can be taken to the offices of the ombudsperson.

In the schedule 2(b) and (i) code of conduct for protection against harassment of women at the work place is mentioned. This code of conduct is for those people for whom it is difficult to understand the difficulties of the law(Raja,2010,p.47). (AASHA) has prepared this bill of 
code of conduct in simple language in English and Urdu as well. This code provides a guideline for the behavior of all employees, including management and the owners of the organization to ensure an environment of work which is free of intimidation and harassment. It is the duty of the management to educate all the employees about this code of conduct and penalties if not follow or break this code of conduct (NSSW, Annual Report, 2010-2011, p.20).

Main objective of this bill is to create a safe environment for women which will free of harassment. This Act mainly addressed two main rights of woman i.e. right to work and right to dignity. This bill made harassment crime for the first time in Pakistan's history. It is a breakthrough. Pakistani women face harassment at streets, at homes, at workplaces and at public places. Women could not utilize their abilities in well manner due to the harassment, it had made working environment very uneasy for women. It is the biggest hurdle in the ways of working women's progress. The objective of this law is to create such a conducive environment, where people feel free to work and earn their living, which will make them economically empowered. Economic empowerment is one of the major dimension of women empowerment. This law was in compliance with the commitment of government to international standard of women empowerment. This law addressed the elimination of all forms of discrimination against women and human rights declaration.

This law would give confidence to women that they are no more on the discriminatory position in the society and they can do something for themselves also they will not have to bear the whistling, leering and unwanted words from the people. They can get complaints registered against such persons.

\section{The Prevention of Anti-Women Practices (Criminal Law Amendment Bill 2011.)}

The Senate passed this bill on December 23, 2011. This bill was tabled after three years in the assembly by Doniya Aziz a parliamentarian of Pakistan Muslim League (Q). This law made three offences unlawful against women (1) to make a woman deprived of her rightful inheritance by using illegal and deceitful means (2)To give the girls in badl-e-sulha to settle the disputes which are civil or criminal .(3)force the women to marriage with Quran according to the traditional values (Moreno \& Rossler,2013,p.48).

Prohibition of depriving women from inheriting property. The person who will deceitfully deprive any woman from her property moveable or unmovable would be punished with imprisonment for a term which will not be less than seven years and will have to pay the fine of 1,000,000 rupees. Section 498B states prohibition of forced marriages. The person who will compel any woman to marry will be punished with imprisonment which will not be less than three years and will be liable to fine of 500,000 rupees. 498C prohibition of marriage with the Holy Quran this law specified the imprisonment not less than three years and five of 500,000 rupees for the person who will compel a woman to marriage with Quran(Criminal Law AmendmentAct,2011).

In Pakistan there are many customs and traditions which are against the dignity of humanity. These customs violate the human rights. Marriage with Quran is defined as an "oath by a 
woman on the Holy Quran to remain unmarried for the rest of the life and not to claim share in inheritance(DawnNews,16Nov,2011). The objective of this bill is to counter all these inhuman practices in the society. Islam is the religion of justice and it granted all the right to women either they are social, economic, political or religious. Quran introduced reforms to upgrade the status of woman. But people made customs to bring the women's position at lower grade. In the rural and feudal areas of Pakistan the women rights are curtailed by the male members. Women are vulnerable to subjugation and anti women practices in these areas of the country. All their rights which have been granted them by their religion and state are used by the male members of the society. Women are used to settle the disputes and are considered as a private property. To use the women for settling the disputes curtails their right of freedom and right to life. In the feudal areas of the country the Jirga culture prevails which settle the matter of disputes by giving the minor girls as the Badl-e-Sulha, Wanni and Sawara culture is mostly prevailing in the tribal areas of the country (Zaheer\&Shameera, 2012, p.176). A minor girl is considered a commodity and is given to the rival families against the blood money. This practice is done in all the provinces of Pakistan with different names as Ijaee in Balochistan Wanni in Punjab Sawara in Khyber Pakhtunkhaw and Sang- Chatti in Sindh (UNDP,2009). It is a worst form of violence against women and sheer violation of teachings of Islam as well as the human rights. A law was made in 2004 as the name of Criminal Law Amendment Act which curbed such kind of inhuman practices and this law was enacted in 2011 to stop violation of human rights. This law was the outcome of the countless struggles of the human rights and women rights activist (Zaheer\&Shameera, 2012, p.104). It is a milestone for the rights of rural and tribal areas women. By depriving the women from their inherited property women could never stood on their own feet. To save the inherited property the male members of the family make marriages of women with the Quran. By this way they would never be able to marry with anybody which is a severe violation of their rights. Under this new law the person who would practice these inhuman acts would be punished imprisonment and would be liable to fine.

\section{Acid Control And Acid Crime Prevention Act 2011 In Pakistan}

In Pakistan women rights are violated through heinous crimes like acid throwing. This is the worst form of crime against women. It is a grave crime which can be occurred on both at public places and in the homes. This crime is mostly committed by the ex-husbands of wives who are jealous with the beauty of their wives and by the boys who send their proposals to the girls and on the rejection of their proposals. They commit this crime to take grave revenge.

Pakistan government and human activists criticized this violence several times. The situation in Pakistan became so sever that Government of Pakistan took a solid step to counter this crime by the enactment of the Acid Control and Acid Crime Prevention Act 2010 in Pakistan. This law recommended imprisonment sentence for fourteen years to life time imprisonment sentence and for fine up to one million. There was no proper legislation for these types of crimes that's why this became common in Pakistani society.(Gazette of Pakistan,2011).

The main objective of this bill was to control the production, import and sale of the acid 
because this crime was prevailing due to the free sale and buying of the acids in the market. The Parliamentarian Marvi Memon introduced this law in the National Assembly. It is mentioned in the bill that this bill is to prevent and protect women from acid crimes. The assertion of new section $336 \mathrm{~A}$ and $336 \mathrm{~B}$, "Whoever causes hurt by means of fire or by any heated substance or by means of any poison or any corrosive substance or acid, or by means of any explosive or arsenic substance or by means of any substance which is deleterious to the human body to come into contact with, to inhale, to swallow or to receive into the body shall be called to have caused hurt by dangerous means or substance"(Newsdesk, 21,Oct,2010).

This bill was a further amendment to the Pakistan Penal Code 1860.In Section 336-B of the amendment it is stated that "whoever causes hurt by coercive substance shall be punished with life imprisonment of either description which shall not be less than fourteen years with a minimum fine of Rs one million"(Mirza,2011,p.3).

Violence against women is an acute problem in Pakistan and its most shocking manifestations are acid attacks. This law placed greater control on the production and use of such substances.

The National Assembly unanimously approved the Acid Control and Acid Crime Prevention Bill, 2010. This bill was tabled by the member National Assembly Bushra Gohar who is the MNA from Awami National party and chairperson National Assembly Standing Committee on Woman Development. This bill was passed unanimously by the whole assembly members. This law was signed by President Asif Ali Zardari on $22^{\text {nd }}$ December. Marvi Memon (MNA) from Pakistan Muslim League (Q) said in the House that "criminal minded people are constantly using acid as a dangerous and devastating act against the woman (Newsdesk, 21Oct, 2010).

This bill criminalizes throwing acid or any other coercive substance on women in attempt to punish, hurt, deface and disfigure them.

Prime Minister Yousaf Raza Gillani congratulated to all the parliament members and said "this reflects the great effort and struggle by women lawmakers of Pakistan which will be praised by international community”( Zia,T,2013).

Senator Neelofer Bakhtiar presented this bill in the Senate and expressed gratitude to the members for supporting the bill because it was the first time that no member opposed this bill in the upper House.

This law will afford greater protection to Pakistani women because in 2009 The Acid Survivors Foundation (ASF) recorded 48 cases of acid attackers and this was more than 33 cases in 2007.

Now this law has been enacted and the criminals know that a law has been passed to counter and limit them doing these types of horrible crimes. Now they will realize that acid attacks are criminalized act which will be punished as well as the seller of the acids would realize the selling of the acids is a crime and the selling is regulated and controlled. Now it is up to the police and implementation authorities that they check and monitor the acid sale and purchase. 
Despite the enforcement of these laws according to Aurat foundation a women's rights organization in the year 2011 almost 8,000 examples of violence were recorded in which 44 were acid attacks. However the making of law is the first step and it is up step towards effective implementation (Zia,T,2013).

\section{The Women In Distress And Detention Fund (Amendment Act) 2011}

This is another bill to provide financial and legal help to distressed women languishing in various jails of the country.

This bill was passed by the upper House of the parliament on Tuesday $13^{\text {th }}$ December 2011. This act was to amend women in Distress and Detention fund Act 1996. Syed Nayyer Hussain Bokhari moved this bill in the House. Before this law, another act entitled women in Distress and Detention fund 1996 and these funds were being administered by the Human Rights wing of the Ministry of Law, Justice and Human Rights. But now the Ministry of Human Rights was formed as a separate entity after the eighteenth amendment to the constitution. The previous ministry was evolved. The funds were also transferred to new Ministry of Human Rights(Year Book,MHR,2011,2012,p.12).

This bill was earlier promulgated by an ordinance by the President of Pakistan on $18^{\text {th }}$ April 2010 with the purpose that the mandate of Ministry of Human Rights is to provide legal and financial assistance to women in distress and detention. In order to make this fund operational under the new ministry law was enacted. After the promulgation of this new law in 2011 the Ministry of Human Rights has authority to use these funds. This fund is used for two purposes, to assist deserving women in detention either under trial, convicted or in the Dar -ul -Aman to provide them jobs, provide them books or in cases of extreme hardships with the purpose of rehabilitation for the women who need medical help, distressed women and their children who needed shelter, to help women who need legal help(Year Book,MHR,2011,2012,p.13). In this way government provided women assistance so that their way towards empowerment and rehabilitation should not be stopped.

\section{Domestic Violence (Prevention and Protection) Act, 2012}

The National Assembly passed this bill in 2009 but it was lapsed because Senate did not pass this bill within the three month period. The legislation of the bill was now to be taken up to the provinces after the passage of the eighteenth amendment in the constitution. On $20^{\text {th }}$ February Senate unanimously passed the Domestic Violence Prevention and Protection Act 2012(Pak Today, 22nd Dec, 2012). This law is leap forward to the women empowerment in Pakistan and it is said that it is the most progressive act which is relating to the violence committed in the four walls of the house. Pakistani Women are considered as private property and domestic violence was not considered as a violence at all. The domestic violence remained an issue of concern. This domestic violence made the violence in the chardiwari (four walls) as a crime or offence which would be punishable as imprisonment and liable to imposition of fines.

This law was presented by Senator Nilofar Bakhtiar in the upper House of the parliament. Although this law was already passed by the National Assembly the lower House of the 
parliament in 2009(Pak Today, 22nd Dec, 2012).

This law is a well drafted bill which shows serious efforts to control the domestic violence against women. The main thing in the Act is that it acknowledged the domestic violence as an offence, as well as this Act acknowledged that it would no more be ignored or remained invisible. This law enabled the victims to have easy access to courts, they will no more have to go to the police for filling the FIR to gain entry in the court.

This law provided the definition of domestic violence as "Domestic violence includes but is not limited to all intentional acts of gender based or other physical or psychological abuse committed by an accused against women, children or other vulnerable persons with whom the accused is or has been in a domestic relationship including but not limited to(Qureshi,2012,p.5).

The definition shows that the scope of the law is very wide, it extends the protection to children and other susceptible persons against domestic violence, to provide them a comfortable environment. Its preamble shows that domestic violence is a gender based violence and which is perpetrated by men against women. It is evident from its preamble that this Act is for the prevention and protection of children and women and it is the main objective of the Act (Qureshi,2012,p.5). The aggrieved person could present an application to the court for seeking relief under this act which shall fix the first date of hearing within the seven days after receiving the complaint. The complaint would be disposed off within period of ninety days. This bill grants authority to the court to issue an interim order at any time and stage of the petition and can pass protection orders and residence order under which it can prohibit the respondent from committing any act of domestic violence aiding or abetting the commission of acts of domestic violence, entering the place of employment of the aggrieved person(Dawnnews,20Dec,2012). Under this Act the court also holds the powers to order the respondent to pay monetary relief to the victim of domestic violence. The respondent would have to bear imprisonment for six months with a fine of Rs 100,000 or more, if he will breach the protection order. Who willbreach the order will have to face imprisonment enhanced for two years with a fine of 200,000 on the violation of second time of the orders(Dawnnews,20Dec,2012).

After the promulgation of Domestic Violence Act, domestic violence is brought into the public domain. The bill responded to the national policy for development and empowerment of women .By introducing positive legislation about domestic violence. Government also responded to the convention on Elimination of All Forms of Discrimination against women.

\section{National Commission on The Status of Women Act, 2012}

National Commission on the Status of Women Act was passed by the Pakistan senate on $2^{\text {nd }}$ February, it was unanimously approved by the senate to protect the women rights against every type of discrimination (UNwomen, news, 7thfeb, 2012).Already a Commission was working with the same name but this new Act provided a new shield to the already existing Commission and gave it financial and administrative autonomy and an independent secretariat. The purpose behind the promulgation of this Act was to promote the legal, 
economic, political and social rights of women which constitution of Pakistan has bestowed them. Pakistan is a signatory to the CEDAW so this Act is for the true implementation of the articles of CEDAW. Under this Act the Commission will have the powers to work in all dimensions of the women empowerment, as social, legal and political. The main function of the Commission was to make policies and recommendations to improve the status of Pakistani women (NCSW, Annual Report,2012). It is consisted of five chapters in which the establishment of the Commission, appointment of chairperson and members, terms of office of chairperson and members, secretariat of the Commission, .functions and powers of the Commission, funds and the annual report of the Commission are mentioned in this Act.

This bill was signed on International Women's day on $8^{\text {th }}$ March. President of Pakistan Asif Ali Zardari expressed his views that the Commission now will play an instrumental role in ensuring protection of women's rights. He promised that the Commission will be an autonomous and independent body to protect the rights of women, as well as President promised that it would play a significant role as a watchdog of women's rights and would help in bringing positive change in policies and legislation(The Gazette of Pakistan,March,10,2012).

It is the duty of the Commission to investigate and gather information on the women's rights regarding issues and will oversee the international commitments made by the government on the issues of women. The status of the chairperson was also changed under the new law. Now the status of chairperson would have the seniority of a state minister, who will send the recommendations directly to the cabinet. This Commission would be consisted of two members from each province and one member from Federally Administered Tribal Areas, (FATA),Azad Jammu and Kashmir, Gilgit Baltistan, Islamabad and two members from minorities and atleast one member should be a woman. The functions of the Commission are to examine the federal government's policies and programmes for the gender equality and women's empowerment. The assessment of their policies is also the function of the Commission. The Commission will also make suitable recommendations after reviewing all laws, rules and regulations which were affecting the rights and status of women.

The Commission will also give recommendations and suggestions to repeal the laws and to make new laws to eliminate discrimination for promoting and safeguarding the women interests and make efforts to achieving the gender equality in the society. The Commission will sponsor the researches for maintaining a database on women issues with the interaction of non governmental organizations. The commission will also inquire the complaints against the violations of women's rights and along with it will regularize the inspection of jails(The Gazette of Pakistan,March,10,2012).

The prime minister of Pakistan has the authority to appoint the chairperson. Khawar Mumtaz has been appointed as the chairperson of the commission who is a well famed women activist and the founder of the WAF. She struggled hard for the women rights and empowerment in Pakistan. It is hoped that under the supervision of this well reputed women activist, Commission will perform best for the women rights in the country (Year Book,NCSW,2011-2012,p.12). 


\section{National Commission For Human Rights Act 2012}

The process to introduce legal reforms for the empowerment of women has been taken seriously by the government. For this purpose National Commission for Human Rights Act was enacted on $4^{\text {th }}$ May 2012 by the parliament of Pakistan and was passed by the President of Pakistan on 30 ${ }^{\text {th }}$ May 2012(Year Book,NCSW,2011-2012,p.13).

This Commission was established with the purpose to broaden the perspective of human rights in Pakistan so that it pursues the cases of violation of human rights diligently. It is already declared that women rights are the human rights The National Commission on the Status of Women has presented its fourth periodic report to the United Nations CEDAW Committee, under the chairmanship of Khawar Mumtaz. This fourth periodic report is the result of the combined efforts of government and civil society organizations. In this report it is shared and informed to UN committee that Pakistan is very much concerned to address discrimination against women and have undertaken interventions to promote and secure the status of women as equal citizens. Although Pakistan is facing extremism within the country, government of Pakistan is very much serious to promote the status of women in Pakistan. It was mentioned in the report that under the eighteenth amendment the devolution of power to the provinces was a historic step towards greater autonomy and space for provincial governments to address social problems. She presented and explained the legislative measures taken by the government to empower the Pakistani women(Khan,A,2013 p.7).

After the $18^{\text {th }}$ amendment the power to make laws about women has gone to provinces. Punjab government also showed commitment to upgrade the status of women by introducing Punjab government package for women empowerment,2012 in which it is mentioned that comprehensive legislation to provide assistance to the female victims of violence shall be enacted by the provincial assembly which will cover all types of gender based violence including domestic violence. These steps would be to minimize the domestic violence in the society. About harassment at work place government will issue notifications for the appointment of ombudsperson under protection against harassment of women at the workplace. Code of conduct for protection against harassment of women at the work place (Punjab women package,2012).

Acid throwing offence would be dealt with the amendment in poisons Act to discourage the acid throwing incidents on women. Acid throwing cases would also be dealt in anti terrorism laws (Punjab women package,2012).

Punjab government on the eve of the International women day on $8^{\text {th }}$ March 2012 announced Punjab Women Empowerment Package 2012(PWEP). This package comprised of multiple reforms in legal, administrative and institutional spheres. It provides new initiatives to secure women's rights and is expected to transform the socio economic status of women. Government has increased quota of women employment from 5 to $15 \%$, special age relaxation for three years and one additional chance of transfer to women has also been notified. However there is a debate going on being discussed that this devolution will play the better role to make the position of women in the country. 
In the year 2013 elections held in Pakistan on $11^{\text {th }}$ May and under the results of these elections the government of Pakistan Muslim League Nawaz group came to power. It is hoped that the process of introducing new laws and repealing discriminatory laws for women protection and their rights would be continued.

In the new elections sixteen women representatives out of 463 candidates were elected for the 324 national and provincial general seats. However sixty seats are reserved for the women in the National Assembly of the country (TheNation,May,17,2013).

Some new and progressive things also came in these elections as a candidate Nusrat Begum was the first representative from the tribal region of Dir. Her election and pitch defies the conservative stance of her constituency. She said that Dir is a very conservative region but I came out because I wanted things to go better so there can be peace and things go better.

In these elections women participated and showed great enthusiasm ,because they knew that the possibility of change and path towards empowerment can be attained by their positive participation(TheNation,May23,2013).

In Pakistan reserved seats for women are $22.5 \%$ which is the same as United Kingdom and better than the United States of America which is 17.8\%.Although all these women are from elite background and those from poor backgrounds always remain excluded from the political system but in the recent elections one women from Bahawalpur from the Pakistan Muslim League $(\mathrm{N})$ and with a very poor background Hasseena Begum has come on the reserved seats for women in the Provincial Assembly of Punjab which is a good sign for women participation.

In the $13^{\text {th }}$ parliamentary session women legislators sponsored 104 private members bills which was the $68.9 \%$ of the total as compared to 47 sponsored by their male counterparts. Women participation will open the doors of women empowerment they will raise the women issues and introduce women pro legislation(TheNation,May23,2013).

\section{Conclusion}

To make laws for the protection of women is a positive thing. In Pakistan a large portion of the society is fighting for the cause of women rights and women empowerment .Now no government can afford to ignore the women's rights because today women have realized their position and status and they will condemn all the actions which will go against towards curtail their position and rights. There is a dire need to make new laws for the women's economic opportunities, employment and social security. The most important component of women empowerment is legal empowerment which guarantees protection of social, economic and cultural rights of women. In Pakistan different strategies are being evolved to achieve the goal of women empowerment. Different governmental and non governmental organizations played an important role to mobilize women to become legally empowered for the protection of their fundamental rights. The women are striving hard to protect their rights through enactment of the laws. There is sufficient legislation available for the protection of women rights in the country. The women are still becoming victims of attempted rape, domestic violence and sufferings at workplaces. They are reluctant to register their complaints due to 


\section{Macrothink}

Journal of Public Administration and Governance ISSN 2161-7104 2013, Vol. 3, No. 4

fear of being defamed in the society and family pressure. The law enforcement agencies are required to be rehashed. The women have lack of confidence upon justice dispensation system. The better implementation mechanism is required for the protection of women rights and make them legally empowered.

\section{Biography}

- Ali, Parveen. Shoukat.(1979). Legal Status of Women in The Third World. Lahore: Aziz Publishers.

- Ali, Parveen, Shoukat,(1980).Human Rights in Islam. Lahore: Aziz Publishers.

- Ali, Azra. .Asghar.(2000).The Emergence of Feminism Among Indian Muslim Women: 1920-1947. New York: Oxford University Press.

- Ali, Shaheen. Sardar.(1995).A Comparative Study of The United Nations Convention on The Elimination of all Forms of Discrimination Against Women, Islamic Laws and the Laws of Pakistan. Peshawar: .Asia Watch and the Women's Rights project.

- Amnesty International.( September 1999). Violence against women in the name of honour.

- Assessment of Women Protection Act, 2006. National Commission on the Status of Women. Islamabad: Pakistan.

- Annual Report. (2010-2012).National Commission on the Status of Women.

- Asia Watch \&The Women's Rights Project.(1992).Double Jeopardy: Police Abuse of Women in Pakistan, New York: Human Rights Watch.

- Bolobhi.org/wp-content/uploads/2012/02/theDVB,2012.pdf.

- Human Rights Watch.(1999). Custom or Crime? Violence against Women in Pakistan. New York: Oxford University Press.

- Dawn News,(2006). January, 6.Friday,.

- Dawn News,(2006). March, 10.Friday.

- Dawn News,(2006).March,9.

- Dawn News,(2007).January, $1^{\text {st }}$.

- Dawn News,(2011).Anti Women Customs .file:///E:/Anti-wmen customs-Dawn.com.htm.16-11-2011.

- Dawn News, January, 4, 2006..

- Dawn.com,(2012)Domestic violence no more a private affair.20-12-2012.

- Government of The Punjab, $2^{\text {nd }}$ April 2012 Services and General Administration Department. 


\section{I Macrothink}

Journal of Public Administration and Governance ISSN 2161-7104 2013, Vol. 3, No. 4

-Goonesekere, Savitri. (2004). Violence, Law and Women's Rights in South Asia. New Delhi: Sage Publications.

- Gazette of Pakistan, Extraordinary, Criminal Law (Amendment Act) 2010.

- Gazette of Pakistan Extraordinary, part, 2nd December, 2006. Protection of Women (Criminal Laws Amendment)Act.

- Human Rights commission of Pakistan Annual Report, 2006.

- Human Rights Commission (2006).State of Human Rights in 2006,Lahore:Pakistan.

-Jahangir, A \&Jilani, H. (1990). Divine sections? A research study of the Hudood Ordinance and their effects on the disadvantaged section of Pakistan society. Lahore: Rhotas Books.

-Jillani, Hina. (1992). Whose Laws? Human Rights and Violence Against Women in Pakistan. New York: Oxford University press.

-Khan, Rabia.(2009)Situational Analysis and Mapping of Women's Rights.submitted to CIDA,Pakistan programme.

-Khan, Tahira. Shahid. (1999).Chained to Customs" The Review.

-Lateef, Shahida. (1990). Muslim Women in India, Political \& Private Realities: 1890s-1980s. London: Zed Books Ltd.

- Law and Justice Commission of Pakistan Releasing the Female Accused on Bail.www.commonlii.org/other/pkjc/reports/48.html.

-Mirza, Naeem.(2011).Seven Pro-Women Laws in Seven Years, Legislative watch, Issue No,38.p.1.www.af.org.pk/Newsletter/ul2011/NLEEnglish.38.pdf.

- Medium Term Development Framework (2012-2013). Government of the Punjab. Ministry of Women Development, Social Welfare and Special Education.

-Mumtaz, Khawar \& Shaheed, Fareeda. (1987). Women of Pakistan: Two Steps Forward, One Step Back. Lahore: Vanguard Books.

-Naheed, Kishwar. (2008). Women: Myth and Realities Lahore: Sang-e-Meal Publishers.

- Newsdesk.org/wp-content/uploads/2010/06/acid-controlact-2010-260110-1.pdf

- Newsdesk.org/wp-content/uploads/2010/06/acid-controlact-2010-260110-1.pdf

- Oette, Lutz.(2011).Criminal Law Reform and Transitional Justice: Humen Rights Perspective for Sudan. England: Asghate Publishers.

- On The Path of Women's Empowerment: A Synthesis of Report of 
Commissions/Committee on the Status of Women, 24 December, 2003. Government of Pakistan, Ministry of Women Development, Social Welfare and Special Education, Islamabad.

-Pak Today.Senate passes Domestic Violence Bill. wed,22 ${ }^{\text {nd }} 2012$. file:///E:senate passes Pak Today.

-Patel, Rashida. (2010) Gender Equality and Women's Empowerment in Pakistan. Karachi: Oxford University Press.

- Pakistan Commission on the Status of Women. Pakistan National Report Beijing +10 Ministry of Women Development Islamabad.

- Pakistan Penal Code. Section-34.

- Pakistani Women: Opportunities and Challenges 2001.mowd.gov.pk.

- Prevention of Anti Women Practices" (Criminal Law Amendment. Act (2011). http://www.na.gov.pk/uploads/documents/1321415693-161.pdf.

- Punjab Women Package for Women Empowerment.(2012).

- Pakistan Commission on the Status of Women, The Report of the Pakistan Commission, Quoted in Pakistan in Islamabad. Pakistan. 1984.

- .Raja, A, Mehreen, (2010).Important New Acts 2010.Lahore: Punjab Book House.

- Sarajuddin, Muhammad. Alamgir. (2011).Muslim Family Law, Secular Courts and Muslim Women of South Asia: A Study In Judicial Activism. New York: Oxford University Press.

- Shafqat, Saeed. (2007). New perspectives on Pakistan: Vision for the Future. New York: Oxford University Press.

- Shaheed, Farida.(1990).Pakistan's Women: An Analytical Description. Lahore: SANJH Publishers.

- Singh, R.S.N. (2008).The Military Factor in Pakistan. New Delhi: Lancer Publishers.

- Syed, Anwar. (1982). Pakistan. Islam, Politics and National Solidarity. Green Wood Publishers.

- Syed, Aslam, Muhammad.(1995). Islam and Democracy in Pakistan. Islamabad: Crystal Printers.

- Sehgal, M. Ikram.(2006).Defence journal,volume9,issue12_volume10,issue12.

- ShirkatGah.(2004). "Why The Hudood Ordinance must be Repealed" Lahore: Women's Resource Center. 
- Shaheed, Farid. (1994). Women in Politics: Participation and Representation in Pakistan. Lahore: Shirkat Gah.

- The Gazette of Pakistan ,Extraordinary March10,2012. www.na.gov.pk/uploads/documents/133180886-398.pdf.

-The Nation, 16, .2013.Women Elected on general seats.www.nation.com.pk/pak-news,May17,2013.

-The Nation.23,2013shaheenkauser, www.nation.com.pk/pak-news,may23,2013

- UN CEDAW Verdict. (2007). (Concluding Comments) on Pakistan's Combined Initial, Second and Third Periodic Report.

- United Nations Convention on The Elimination Of All Forms of Discriminations against Women.

- U N Development Programme. (2009).Facets of Violence Against Women Gender Justice and Protection Project.

- United Nations Entity for Gender Equality and Empowerment of Women.(7feb2012).www.unwomen.org/en/news/stories/2012/2/historic.

- Waddy, Chris. (1980). Women in Muslim History. London: Longman group Ltd.

- Walters, Margaret.(2000). Feminism: Avery Short Introduction. Oxford University Press.

- Weiss, Anita, M. (2012). Moving Forward with the Legal Empowerment of Women in Pakistan. United States Institute of Peace .www.usip.org

- Welchman, Lynn\& Hossain Sara. (2005). 'Honour': Crimes, Paradigms, and Violence Against Women. Karachi: Oxford University Press.

- Year book, 2003-2004. Global vision publishing House. New Delhi. Government of Pakistan, Ministry of Women Development.

- Year Book,(2004).Ministry of Women Development in Pakistan.

- Year Book,(2005).Ministry of Women Development in Pakistan.

- Year Book,(2006).Ministry of Women Development in Pakistan.

- Year Book,(2007).Ministry of Women Development in Pakistan.

- Year Book,(2008).Ministry of Women Development in Pakistan.

- Year, Book.(2011-2012).Ministry of Human Rights. Government of

Pakistan.

- Zafar, Fareeha. (1991). Finding Our Way: Readings on Women in Pakistan. Lahore: ASR Publications. 
- Zaheer \& Shamreeza. (2012).Legal Protections Provide under Pakistani Law against Anti Women Practices: Implementation Gaps between Theory and Practices.

- Zia,Taiba.(2013). Acid Violence in Pakistan, Los Angles, UCLA centre.ww.escholorship.org/ucl/item/65v95821.

- Zia, S, Afiya. (2010). A Policy Frame Work for Women's Equal Rights. Study for the National Commission on the Status of Women. 